\title{
The Baltic TRANSCOAST approach - investigating shallow coasts as terrestrial-marine interface of wa- ter and matter fluxes
}

Manon Janssen ${ }^{1}$, Michael E. Böttcher ${ }^{2}$, Martin Brede ${ }^{3}$, Hans Burchard ${ }^{4}$, Stefan Forster ${ }^{5}$, Ulf Karsten $^{6}$, Peter Leinweber ${ }^{7}$, Bernd Lennartz ${ }^{1}$, Gregor Rehder ${ }^{8}$, Hendrik Schubert ${ }^{9}$, Heide Schulz-Vogt ${ }^{10}$, Inna M. Sokolova ${ }^{5}$, Maren Voss ${ }^{10}$, and Gerald Jurasinski11*

${ }^{1}$ Soil Physics, Faculty of Agricultural and Environmental Sciences, University of Rostock, Rostock, Germany

${ }^{2}$ Geochemistry and Isotope Biogeochemistry, Leibniz Institute for Baltic Sea Research Warnemünde, Rostock, Germany

${ }^{3}$ Fluid Mechanics, Faculty of Mechanical Engineering and Marine Technology, University of Rostock, Rostock, Germany

${ }^{4}$ Physical Oceanography and Instrumentation, Leibniz Institute for Baltic Sea Research Warnemünde, Rostock, Germany

${ }^{5}$ Marine Biology, Faculty of Mathematics and Natural Sciences, University of Rostock, Rostock, Germany

${ }^{6}$ Phycology and Applied Ecology, Faculty of Mathematics and Natural Sciences, University of Rostock, Rostock, Germany

${ }^{7}$ Soil Science, Faculty of Agricultural and Environmental Sciences, University of Rostock, Rostock, Germany

${ }^{8}$ Marine Chemistry, Leibniz Institute for Baltic Sea Research Warnemünde, Rostock, Germany

${ }^{9}$ Aquatic Ecology, Faculty of Mathematics and Natural Sciences, University of Rostock, Rostock, Germany

${ }^{10}$ Biological Oceanography, Leibniz Institute for Baltic Sea Research Warnemünde, Rostock, Germany

${ }^{11}$ Landscape Ecology, Faculty of Agricultural and Environmental Sciences, University of Rostock, Rostock, Germany

* Correspondence:

Dr. Gerald Jurasinski, gerald.jurasinski@uni-rostock.de 


\begin{abstract}
In Baltic TRANSCOAST we study the physical, biogeochemical, and biological processes at the land-ocean interface. The coastal zone is heavily impacted by various human activities as well as by geomorphological and climatic processes - on both the land and the sea side. Landsea interactions at low lying coastal areas that are often dominated by peatlands, and are a common feature along the Baltic Sea coast, are not well understood. The core hypothesis of Baltic TRANSCOAST is that the shallow sea and the terrestrial peatland have a mutual impact on each other with far-reaching consequences for water and energy fluxes, matter cycling and the biota. The interdisciplinary research focuses on the significance of flooding frequency and duration on biogeochemical processes by concentrating the investigations on three comparison sites. We are assessing how changing boundary conditions (such as climate and land use) affect the hydrology, biota and biogeochemical processes in coastal wetlands and the adjacent marine ecosystem.
\end{abstract}

\title{
1. Background
}

It is estimated that between half a billion and a billion people live in coastal areas (Bollmann et al. 2010, Neumann et al. 2015) with an upward trend and increasing pressure by buildings (ports, wind farms, coastal protection structures such as dikes and dams), agriculture and tourism. On shallow coasts, especially in sections with large lowland areas on the land side, the transitional zone between land and sea is particularly broad and takes on the character of an ecotone (Attrill \& Rundle 2002). Climate-induced sea level rise as well as periodic (tidal range) or aperiodic (storm surges) variation of the water level can affect large areas on both sides of the coastline. The coastline itself is rarely studied as an interface for the exchange of energy, water and matter (as opposed to e.g. estuarine transport), although flow and transport processes across the ecocline and corresponding impacts on (micro)biological and hydro-biogeochemical processes on both sides of the coastline can be expected (e.g., Rullkötter 2009, Gätje \& Reise 2012).

In the study area of the first phase of Baltic TRANSCOAST, the nature reserve "Heiligensee und Hütelmoor", both the Warnow river outflow and the direct exchange across the coastline affect the coast, whereby their proportions vary depending on the wind and current situation (Jurasinski et al. 2018, Lange 2018, Lange \& Burchard 2019). River plumes can contribute to efficient transport perpendicular to the coast (Hofmeister et al. 2013), and interaction with coastal upwelling and density gradients (Horner-Devine et al. 2017) may play a major role for mixing and transport processes (Lange 2018). Numerical simulations of flooding scenarios of coastal sections can help to assess the risk potential of flooding in times of accelerated sealevel rise (Pasquier et al. 2018).

Rising sea levels can be observed worldwide due to the global rise in temperatures (Church et al. 2013). Recent studies had to adjust the speed of the sea level rise (e.g., Nerem et al. 2018), because the sea level rises faster than previously thought. In the southern Baltic this process is reinforced by an isostatic descent of the coast (Johansson et al. 2014). Recent studies predict an increase in storm surge levels in the Baltic Sea based on various regional climate scenarios 
(e.g., Gräwe \& Burchard 2012, Weisse et al. 2014, Soomere \& Pindsoo 2016). In a comparison of European coasts, one of the highest increases in storm surge levels is predicted for the Baltic Sea (Vousdoukas et al. 2016). Our own results within the framework of Baltic TRANSCOAST show that the probability of saltwater intrusions on flat coastal sections of the Baltic Sea is increasing (Jurasinski et al. 2018).

In the southern Baltic region, increased winter precipitation due to climate change is predicted (Maracchi et al. 2005, Spekat et al. 2007, BACC II Author Team 2015). Since the winter halfyear (November - April) is the dominant period of runoff formation in this region, a corresponding increase in water levels on land is to be expected. The combination of coastal subsidence (Hünicke \& Zorita 2016) with rising sea levels (Grinsted et al. 2015) and the predicted increase in winter precipitation in the future is expected to lead to a significant increase in land-sea interactions and an expansion of the area of the coastal system (Jurasinski et al. 2018, Nicholls et al. 2007).

Mecklenburg-Vorpommern accounts for about $2000 \mathrm{~km}$ of the $2600 \mathrm{~km}$ long German Baltic Sea coast (StALU-MM, 2015). From west to east the flat coastal sections increase and often coastal peatlands are located on the land side of the coast. The latter cover approximately 40,000 ha of the land area of Mecklenburg-Vorpommern. They play an important role in buffering the exchange of water as well as of dissolved and particulate matter.

The nature reserve "Heiligensee und Hütelmoor" is a coastal paludification fen (Stüdemann 2008), while most of the coastal peatlands of Mecklenburg-Vorpommern were created by frequent, aperiodic flooding (Succow \& Joosten 2001), which leads to the emergence of coastal flooding peatlands. Coastal peatlands are characterised by their low elevation and regular flooding. Land-side drainage measures, which lead to lower water levels in the peat body and thus to lower gradients towards the sea, promote the inflow of seawater into the peatland without coastal protection measures (Jurasinski et al. 2018). At some coastal sections, the natural exchange of water and matter is now reinvigorated by abandoning or dismantling dikes, as it happened in the study area some years ago. The resulting re-dynamization of the coast and the return of natural exchange processes is considered desirable both from a nature conservation and scientific point of view (White \& Kaplan 2017, Baldwin et al. 2019). One reason, for example, is the hope that functioning coastal wetlands will grow with the sea levels rise (Karstens et al. 2016), which other studies refute, though (Jankowski et al. 2017). The rewetting and renaturalisation of wetlands and peatlands is also seen as important for restoring ecosystem services such as carbon storage, water and nutrient retention or provision of habitat (Vasander et al. 2003, Bonn et al. 2016, Anderson et al. 2019).

Our investigations at the Hütelmoor site show that small hydraulic gradients can lead to a long residence time of the groundwater before it reaches the sea (Jurasinski et al. 2018). The flow and transport processes within the peat affect the recharge of the aquifer (communicating with the Baltic Sea) and are linked to structural properties. In contrast to mineral substrates, knowledge on dominant flow paths in fen peat is scarce. Evidence shows that flow processes in organic substrates are determined by anisotropy (Gebhardt et al. 2012) and a dual pore system (Rosa \& Larocque 2008). Macropores in peat as well as shrinkage cracks can represent preferred vertical and horizontal flow paths and thus influence transport processes (Rossi et 
al. 2012). It is largely unknown to what extent physical peat properties influence biogeochemical processes (Rezanezhad et al. 2016), making it difficult to estimate water and material flows along the ecocline of coastal peatlands. Recent studies demonstrate the heterogeneity of peat bodies, especially in strongly degraded peat, with fundamental effects on water fluxes (Liu \& Lennartz 2019) and transport of dissolved substances (Liu et al. 2016). The influence of salt on hydro-physical properties appears to be lower than expected (Gosch et al. 2018), but systematic studies with different duration and intensity of salt influence are lacking. The close interaction between water levels and matter cycling or gas emissions in peatlands is now well understood (e.g., Jurasinski et al. 2016) and it is clear that peatlands are the most important natural methane source globally (Anderson et al. 2010). However, there also seems to be a large small-scale variability within peatlands (Hendriks et al. 2010, Koch et al. 2014), which points to the influence of plants (Dias et al. 2010) and microorganisms (Liebner et al. 2015, Wen et al. 2018) or substrate properties (Lengerer \& Kazda 2018).

The importance of small-scale interactions between water and trace gas release, e.g. in the rewetting of peatlands, has repeatedly been pointed out (Holden 2005, Glatzel et al. 2008). In addition to water levels, temperature plays an important role for the cycling of substances in peatlands, with warmer conditions presumably leading to increased microbial activity and a loss of $\mathrm{C}$ and other elements (e.g. N and P) as dissolved organic matter (DOM) and in gaseous state. Salt and brackish water inputs into coastal peatlands are typically associated with an increase in sulfate concentrations. Peatlands and marshes with a marine influence are therefore mostly thought to have low methane emissions (Bartlett et al. 1987, Giani et al. 1996, Witte \& Giani 2014), since sulfate reduction inhibits methanogenesis because of the better energy yield of sulfate reducers compared to that of methanogens (Dean et al. 2018). However, high methane emissions can also occur under the influence of brackish water and, thus, under relatively high sulfate concentrations (Heyer \& Berger 2000, Hahn et al. 2015). A small-scale, vertical separation of sulfate reduction and methanogenesis (Jurasinski et al. 2018) and a significantly higher abundance of methanogenic compared to methanotrophic microorganisms (Wen et al. 2018) could be possible explanations for sustained relatively high methane emissions. These findings are supported by measurements in shallow Baltic Sea water, where methane concentrations were increased by peat deposits (Jurasinski et al. 2018).

The transitional area between land and sea is characterised by the influx of water through subsurface seawater intrusions (Sanford 2010) and floodings. The flow of water and solutes towards the sea takes place as groundwater exfiltration ('Submarine Groundwater Discharge' (SGD), Schlüter et al. 2004, Burnett et al. 2003, Andersen et al. 2007, Szymczycha et al. 2012). The water can consist of actual groundwater or recirculated seawater. The latter is the main component of SGD in many situations (e.g., Church 1996, Burnett et al. 2003, Böttcher et al. 2019). SGD can, independently of river estuaries and other point sources, introduce dissolved organic matter (DOM) and nutrients into the sea (e.g. Andersen et al. 2007, Knee \& Paytan 2011, Donis et al. 2017) and thus also influence colonization by living organisms in coastal waters (Liu et al. 2017). SGD was detected on German coasts both in the tide-influenced North Sea (e.g., Moore et al. 2011, Jeandel 2016, Reckhardt et al. 2017) and in the largely tide-less Baltic Sea (Piekarek-Jankowska 1996, Massel 2001, Peltonen 2002, Kotwicki et al. 
2014, Donis et al. 2017, Böttcher et al. 2019). The detection of SGD in systems with only weak hydraulic gradients is a challenge; however, in a part of the investigated coastal section it has been possible to qualitatively detect the occurrence of SGD using various methods (Jurasinski et al. 2018). On the southern Baltic Sea coast, the exchange of sediment-water boundary layers may be influenced by peat layers extending into the shallow coast (Kreuzburg et al. 2018).

Marine coastal sediments are often characterised by relatively coarse grain sizes (sand and gravel) and less well sorted than sediments in greater water depths (Forster et al. 2003). Since resuspension and coastal parallel transport are frequent, sediments are quite permeable and the upper layers are physically unstable, highly mobile habitats. The benthic-pelagic coupling is very strong in shallow waters and increases with decreasing water depth. Karow (2017, 2018) was able to quantify the temporal and spatial propagation behaviour of the groundwater by turbulent transport. This improved our understanding of the ground-level mixing processes and forms the basis for future flow-physical modeling. The hydraulic conductivity of the sediment has a direct influence on the flow near the ground surface and thus influences the material dispersion, especially in shallow water. The surface structure of the sediment, such as the formation of ripples, affects the velocity and concentration profile as well as the production of turbulence (Smyth et al. 2002). The hydraulic properties of marine sediments can change rapidly and strongly due to wave effects and bioturbation. However, the connections between SGD, pore water transport and ground-level circulation at the sediment-water interface are not yet well understood. Wave movements and hydrodynamic processes at this interface definitely lead to inflow and outflow of pore water (Massel 2001, Feddersen 2012). Oxygen and organic material are transferred to deeper sediment layers and, thus, gradients in the redox potential are altered, which in turn influences biogeochemical processes such as denitrification and/or iron, manganese or sulfate reduction (Huettel et al. 1998, Huettel et al. 2003, de Beer et al. 2005, Gao et al. 2012). A better understanding of the role of physical and biogenic oxygen transport in coastal sediments is urgently needed.

The availability of oxygen plays an important role for the zoobenthos (Schade et al. 2019), which in turn play an important role as bioturbators of the loose sediments in the Baltic Sea. Bioturbation of the sediment is associated with high energy consumption for mussels (Haider et al. 2018, Winter et al. 2012), which is why additional stress moments, such as strongly changing salinity, temperature and oxygen concentration, all of which can occur increasingly in coastal areas, can impair bioturbation and/or the bioirrigation potential of the benthic fauna. The high energy demand due to multiple stressors can move populations of bioturbators into bioenergetically strained states and, thus, have a negative effect on the maintenance of central ecological functions or even on the survival rate (Sokolova 2013). With regard to the combined effects of multiple stressors on the homeostasis of marine bioturbators, there is a considerable need for research.

Primary production is typically high in shallow marine waters such as the Baltic Sea and takes place mainly in the pelagic zone (Schiewer \& Schubert 2004). However, the analysis of benthic primary production in shallow water systems has mostly been neglected, although microphytobenthos and benthic macrophytes realise most of the primary production in shallow wa- 
ter systems. Gocke et al (2012) have shown, for example, that seaweed and macroalgae can bind over $100 \mathrm{~g} \mathrm{C} \mathrm{m}^{-2} \mathrm{a}^{-1}$. A study by Cahoon (1999) suggests that up to $60 \mathrm{~g} \mathrm{C} \mathrm{m}^{-2} \mathrm{a}^{-1}$ primary production by benthic diatoms can be added in the temperate climate zone of the northern hemisphere. In the southern Baltic Sea even higher values, from 75 to over $100 \mathrm{~g} \mathrm{C} \mathrm{m}^{-2} \mathrm{a}^{-1}$, were measured (Meyercordt \& Meyer-Reil 1999), but a considerable spatial differentiation is to be expected. Nutrient inputs are a driving element of spatial variability in primary production. The significance of phosphate storage and release for the phosphorus cycle in the sea or in the transition area from fresh water to the sea has so far only been investigated exemplarily (Schulz \& Schulz 2005). It was shown that the environmental conditions that lead to the degradation of polyphosphate can be different in marine bacteria than, for example, in fresh water in sewage treatment plants (Brock \& Schulz-Vogt 2011, Schulz-Vogt et al. 2019). However, it appears that only certain groups of unusually large bacteria can play such a key role in the phosphorus cycle (Schulz-Vogt et al. 2019).

Since the majority of coastal peatlands in northeast Germany have been poldered, drained, and used for agriculture, they now contain large amounts of nitrogen compounds whose conversion and transport is unknown. Similarly, the role of slow warming (Weedon et al. 2012) and the interaction of nitrogen compounds in soils with brackish water is largely unexplored. The increased salinity causes the desorption and accordingly a higher discharge of ammonium (Ardón et al. 2013, Helton et al. 2014, Lamers et al. 1998). So far it is only known that precipitation containing $\mathrm{N}$ has negative effects on the growth of mosses (Vitt et al. 2003) and that warming leads to the mobilisation of compounds and bacterial activity (Weedon et al. 2012). So far, there is little information on the extent to which changes in the chemical milieu in the transition zone from freshwater to seawater change microbial activities and what consequences this has for different element cycles.

\section{The Baltic Transcoast Approach}

\subsection{Premise}

Baltic TRANSCOAST is a Research Training Group jointly hosted by the University of Rostock and the Leibniz Institute for Baltic Sea Research, and financed by the German Science Foundation. The hitherto restricted knowledge on land-sea interactions is due to the fact that the complex processes and inter-relationships are only addressable in an interdisciplinary research approach with closely cooperating marine and terrestrial scientists from various institutions. We therefore combine researchers from the fields of i.a. soil physics, landscape ecology, ecology, fluid mechanics, marine biology and biogeochemistry and oceanography. Baltic TRANSCOAST is carried out by 14 principal investigators, complemented by many distinguished national and international cooperation partners and guests. The first cohort of $13 \mathrm{PhD}$ students started in 2016, the second cohort has just begun their research in 2019. Additionally, up to 12 associated $\mathrm{PhD}$ are working on their theses in close collaboration with Baltic

TRANSCOAST. All PhD students are supervised jointly by researchers from the marine and terrestrial side, and they participate in summer schools and courses tailored to their needs. 
The trained doctoral students thus have an extraordinarily comprehensive understanding of marine and terrestrial processes.

\subsection{General idea}

The coastline appears to act as a boundary between terrestrial and marine systems, but in fact there are close interactions between these two environmental compartments. These interactions manifest themselves, among other things, through freshwater discharge into the Baltic Sea and saltwater intrusion into the peatland. Solute transport into the Baltic Sea or into the peatland modifies biogeochemical processes to a hitherto unknown extent. The overall objective of all Baltic TRANSCOAST work is therefore to deepen the basic understanding of the influence of land-borne processes on the marine coastal zone and sea-borne processes on the terrestrial coastal zone. This central research idea is of fundamental relevance for the system understanding of shallow coasts, which in turn is urgently needed for future management strategies to protect against the consequences of land use and climate change.

Baltic TRANSCOAST implements a systematic and interdisciplinary research approach, in which the coast and the physical and biogeochemical processes are considered as a continuum (Fig. 1). The topic requires that the participating scientists cross borders in the truest sense of the word, and cross their individual disciplinary borders. Only with a process understanding for the respective other environmental compartment will it be possible to meet the challenge of the complexity. For this reason, the research topics are always approached by researchers from the marine and terrestrial sides together.

The central research idea will be expanded or deepened for the second phase of the Research Training Group on the basis of the findings gained during the first phase. On the basis of geochemical data (stable isotopes, age dating of groundwater) as well as through geohydraulic modelling our previous work shows that water and material fluxes occur across the coastline at the Hütelmoor research site. Flooding of the site during a storm surge in January 2019 (after 20 years of freshening) confirm the main hypothesis of Baltic TRANSCOAST regarding the mutual climate-induced exchange between sea and land and open up exciting possibilities to investigate the dynamics of the entire system.

In Baltic TRANSCOAST, water dynamics in the coastal peatland are the central control variable for biogeochemical processes and material flows. Sea-level dynamics, estuarine circulation (Warnow river) and groundwater dynamics in the coastal peatland area have been determined and modelled to form the basis for our future research, in which we will link land- and sea-side water dynamics. The aim is the long-term simulation of the hydrodynamic-geochemical interactions between peatland and sea, e.g. based on the duration and frequency of flooding events. 

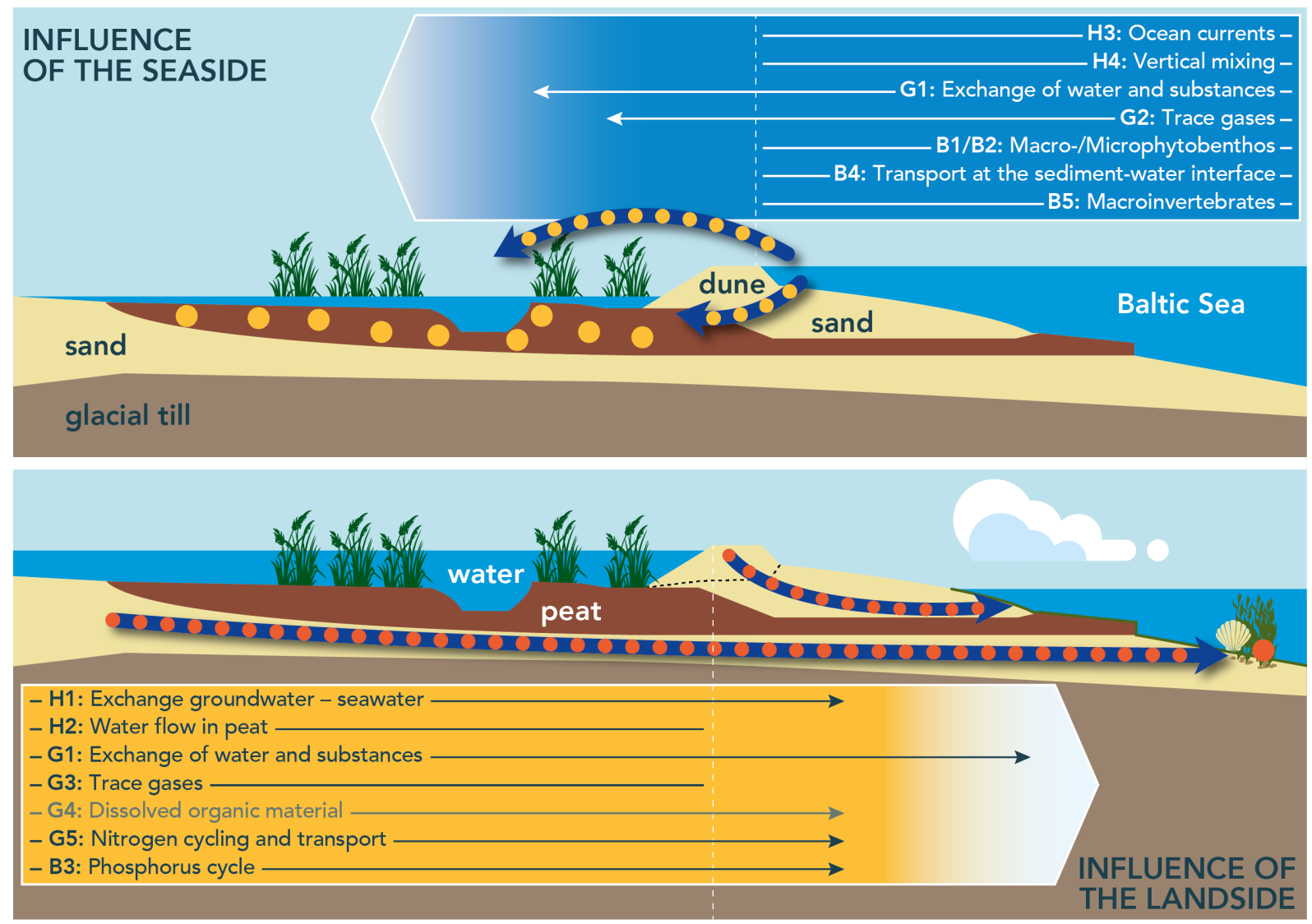

Fig. 1 Schematic representation of the research concept. The project areas are based on a hydro-physical $(\mathrm{H})$, biogeochemical $(\mathrm{G})$, and biological (B) focus and approach their research objects from the land or from the sea side $(\rightarrow \leftarrow)$. The numbers refer to the research topics (cf. section 5).

The land-side consequences of flooding events on biogeochemical processes, though, cannot be structured into a binary scheme - with or without flooding events. Rather, the duration and frequency, i.e. the intensity of flooding events, and the salinity are the gradients along which processes are aligned (Fig. 2). The monitoring of process variables at sites that are either unaffected by brackish water (Drammendorf until early 2020), occasionally flooded (decadal, Hütelmoor) or frequently flooded (Karrendorf) is a prerequisite for estimating the climate and management impact on shallow coasts (Fig. 2). In this respect, investigations at comparative sites represent an important basis for the expansion of our understanding of the prevailing processes.

The central idea comprises the research questions of how microbial processes and the resulting geochemical fluxes in coastal peatlands change due to the influence of brackish water and how freshwater inflow impacts the coastal biota. This will be supported by joint central experiments (mesocosms) with controlled boundary conditions.

\subsection{Research fields}

In Baltic TRANSCOAST all research is carried out in research topics that are each anchored in one of three main research fields: i) hydrophysical, ii) biogeochemical, iii) biological research field. From this anchorage the research is developed inter-disciplinarily with strong links between the single research topics within and across research fields. 


\section{Hydrophysics (H)}

In the research field hydrophysics $(\mathrm{H})$, the water balance and flow dynamics along and across the coastline are addressed. The water balance in coastal peatlands is determined by both, sea level dynamics and water balance of the catchment area and the resulting groundwater regime. While research in the first phase focused on the fundamental dynamics of the coastal peatland and the coastal sea (Jurasinski et al. 2018), the focus will now be on long-term changes and the interactions between peatland and sea and their variability. On the one hand, extreme events and their effects (e.g. flooding) are considered, and on the other hand, consequences of slowly changing external drivers, such as sea-level rise and global warming, are investigated.

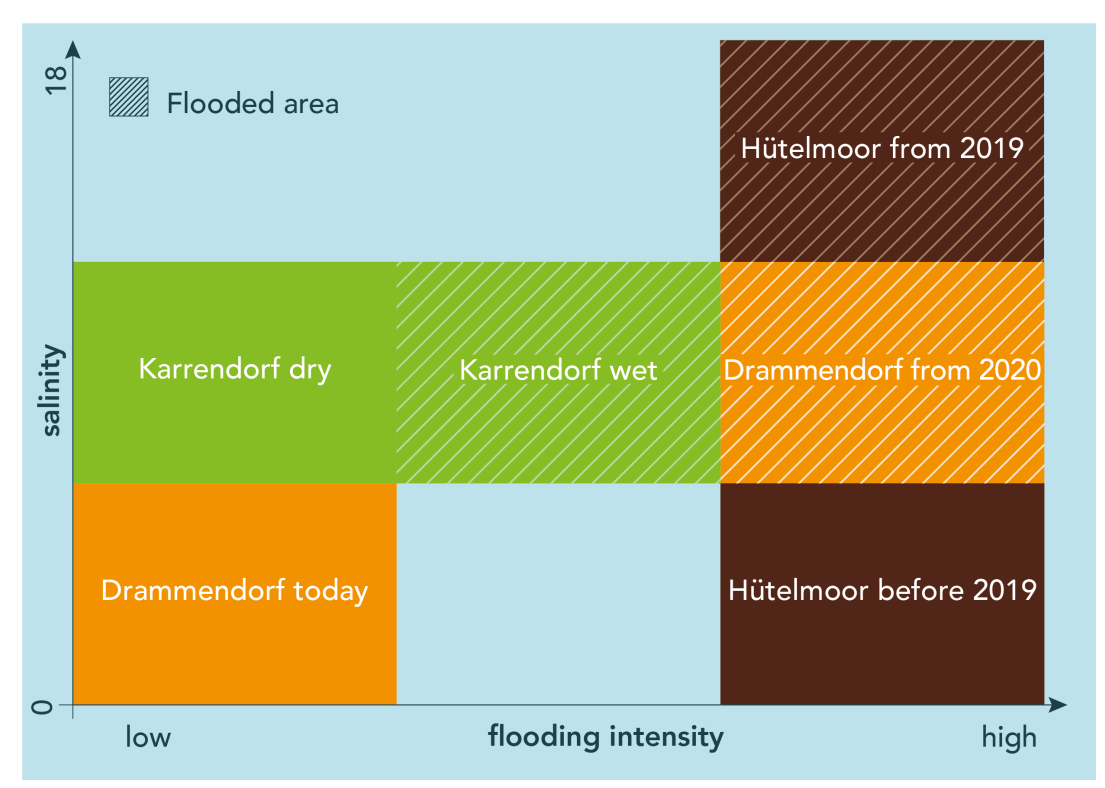

Fig. 2 Biological and geochemical processes at coastal peatland sites in the southern Baltic Sea are controlled by the duration and fre $^{-}$ quency of flooding events with brackish water. For details on the different locations see Chapter 3.

In the course of sea-level rise and the abandonment of coastal protection in the area of peatlands, a significantly increased frequency of flooding events is expected. These extreme events represent an ideal opportunity to measure and model the water balance and material cycles of the peatland-sea system. Important questions here are how water and salt in particular propagate through the coastal peatland as a result of flooding and whether and on which routes they are transported back into the sea. Will groundwater discharge increase sharply after flooding events, or will a large part flow back directly into the sea via the ditch system and estuary? How long does the salt remain in the coastal peatland? Which roles do precipitation and evaporation play for the residence times? What role does the highly variable salt content, which can typically fluctuate by $100 \%$, play in the coastal foreland? Are inflows of saltwater over the coastal dune or over the estuary and the ditch system of greater importance in flooding events? In addition to the previous study area "Heiligensee and Hütelmoor", scenarios for the coastal sections of the two other study areas (Polder Drammendorf and Karrendorfer Wiesen) are also calculated and made available to the other topics within the framework of the nested model system for the coastal ocean.

The important role of flooding events is that salinization of the peat body results in a cascade of biogeochemical processes and transformations, which are investigated in Baltic 
TRANSCOAST's research priority G. In addition to the analysis of individual events, it is therefore important to record the statistics of flood events.

In the first phase of Baltic TRANSCOAST hydrodynamic models for the coastal ocean and hydraulic models for the coastal peatland were developed. The coupling of both models and the integration of biogeochemical process chains will be a major challenge for the 2 nd phase. Important results of the individual topics will be the definition and process parametrisation in the area of the interfaces between coastal peatland and coastal sea, i.e. above all in the area of the sediment-water interface. Sea state plays a decisive role here, as it can reach dynamically down to the bottom in shallow water (H3). The variable composition of the seabed (orography, sediment composition, vegetation) is of particular importance with regard to groundwater discharge and substance transport locally in the boundary layer and regionally in the coastal waters (H4). The more frequent flooding of coastal peatlands with salt water leads on the one hand to altered biogeochemical conversion processes and an increased discharge of e.g. ammonium via surface runoff or submarine groundwater discharge into the Baltic Sea (H1), and on the other hand to altered physical peat properties $(\mathrm{H} 2)$.

\section{Hypotheses in research field $\mathrm{H}$ :}

- Accelerated sea-level rise and increasing storm frequencies will lead to significantly more frequent flooding events. This may lead to an accelerated change in coastal peatlands and to an increased discharge of dissolved substances.

- Flooding events have a significant influence on the hydraulic properties of the peat body and these affect the biogeochemical processes.

- The state of the sea in the near-shore area is the dominant driver for the dispersion of submarine groundwater discharge into the coastal sea on tidal-free open flat coasts.

- Sediment surface structures, e.g. ripples, sea grass or mussel beds, influence the length scales and time constants of turbulent transport in the soil boundary layer.

- The combination of swell, turbulent mixing and mean current determines the transport of substances locally in the soil boundary layer and the dispersion of substances in the coastal waters.

\section{Biogeochemistry (G)}

Peatlands are typically water-saturated and show low redox potentials, which has strong implications for carbon and nutrient turnover and also affects adjacent soils and/or sediments. In coastal areas, the special biogeochemistry of peatlands is additionally determined by salinity. Seawater inflow during storm floods or through underground intrusions and the subsequently increased salt content can affect for example, carbon release or carbon fixation rates. Alternative metabolic processes can be triggered by the influx of sulfate (Jurasinski et al. 2018, Koebsch et al. 2019). The availability and cycling of dissolved sulfate is of great importance for the cycling of carbon and nutrients such as nitrogen and iron. In contrast, when the hydraulic gradient is going from the land to the sea, submarine ground water discharge (SGD) 
can possibly lead to a significantly higher carbon or nutrient release, which may then lead to significant changes in the biogeochemical conversion processes in coastal waters (see e.g., Böttcher et al. 2019), with possible effects on greenhouse gas production and emission.

In Baltic TRANSCOAST we investigate the carbon, nitrogen, phosphorus and sulfate transport pathways across the coastline to better understand the complex interactions of salinity, substrate availability, water and matter exchange and the corresponding geochemical signals in the peat and the Baltic Sea sediments. Pore waters and sediment as well as peat substrates are sampled in depth profiles along transects parallel and normal to the land-sea ecocline and analyzed with respect to the concentrations and composition of the stable isotopes of various dissolved, particulate and gaseous components to characterise the prevailing biogeochemical processes. Investigations on the composition of microbiological communities and vegetation and measurements of gas exchange between sediment and water body (sea side) or peat/vegetation and atmosphere (land side) as well as of production rates will allow a better understanding of the contributions of the biota. The analysis of the composition of the coastal waters as well as in the coastal peatlands allows to determine the exchange of water and substances between sediments/peat bodies and the water column (benthic-pelagic coupling).

Overall, we want to generalise the gained knowledge and deepen our process understanding in the 2nd phase of Baltic TRANSCOAST to better understand the mutual influence of the most important biogeochemical material cycles $(\mathrm{C}, \mathrm{N}, \mathrm{P}, \mathrm{S}, \mathrm{Fe})$. This work should allow for causal interpretation of the observed dynamics of land- and sea-side greenhouse gas production and emissions as well as of nutrient transport to the adjacent shallow water areas.

\section{Hypotheses in research field $G$ :}

- Salt water flooding leads to increased release and thus to discharge of ammonium via the ditch system.

- The aperiodic flooding of peat bodies with brackish water modifies the degradation processes of peat and the release of organic matter.

- These changes lead to modifications in the reactive transport pathways of various forms of carbon, nitrogen, phosphorus and metals to adjacent coastal waters.

- The exchange of substances between coastal waters and coastal peatlands (and vice versa) results in changes in the microbiologically determined turnover processes.

- Changes in microbiology determine the production of trace gases as electron acceptors and donors are shifted between compartments (e.g. influx of sulfate into the peatland, influence on bioavailability of iron by DOM input into coastal waters).

- The influence of brackish water changes the vegetation in the coastal peatland, which in turn has an impact on production and emission of trace gases.

\section{Biology (B)}

The research field biology in Baltic TRANSCOAST focusses on the assessment of the influence of multiple stressors on the metabolic performance of organism communities. This work 
is an important addition to the analysis of biogeochemical exchange processes at the land-water interface because organisms and biogeochemistry are interrelated. Of special interest is the understanding of the reaction dynamics of key organisms to the increased variability of the salinity, temperature and nutrient regime caused by the exchange between the sea-side shallow water area and the land side flooding area. Based on the results of the first phase, the land side flooding area is now also included in the investigations. The inclusion of non-marine sediments/soils, which are exposed to permanent and varying salt influence due to flooding, complements the investigations with an important and so far not considered component, so that the prognostic capacity is extended. The investigations of the B topics are closely linked to the work on coastal geology, chemistry and hydrology of the H topics, which capture the necessary framework conditions and provide fundamental contributions to the G topics, which analyse the biogeochemical processes.

The topics B1 (macrophytes) and B2 (microphytes) cover the photoautotrophic range; B3 and B4 deal with the microbial component and B4 and B5 deal with the benthic fauna. Common to all areas is the concentration on the recording of the influence of the variability of salt, temperature, oxygen and nutrient conditions, which, depending on the hydrological conditions, lead to aperiodically occurring phases of multiple stress. B1 and B2 will mainly investigate photosynthesis performance and the resulting changes in dominance of primary producer communities on land and water. The investigation of the microbial influence on the phosphorus cycle, which is a key factor for material flows in the investigated area, is the focus of B3's work. B4 and B5 are dedicated to the exchange processes at the sediment-water boundary layer realised by the bioturbating fauna. B4 will focus on the effects of multiple stress on the oxygen demand of sediments and oxygen input to sediments, while B5 will follow an organismic approach. By establishing an energetic balance of stress-induced need for acclimation and thus limited potential for energy absorption, a causal analysis is to be carried out that flows into a predictive model and can integrate the results of B1 to B4. In order to characterise the abiotic framework conditions, especially the frequency and amplitude of salt, nutrient and temperature fluctuations, the B topics are dependent on the investigations of the $G$ topics and, in return, will feed their punctual, high-resolution data sets into these topics. For their part, the results of the B topics will be incorporated into the interpretation and causal analysis of the material flow investigations carried out in the H topics.

\section{Hypotheses in research field $B$ :}

- Multiple stress not only causes changes in the composition of shallow water organism communities, but also influences the functionality and cycling performance of material flows.

- The remineralisation performance in the land-sea boundary area is subject to a strong dependence on intensity and frequency of disturbance events with corresponding consequences for the carbon and oxygen balance of sediments and open water areas.

- The contribution of sediment fauna to storage and cycling processes is a key element in the functioning of shallow water ecosystems and is particularly sensitive to multiple stress situations due to energetic feedback effects. 
- Microbial storage of limiting nutrients (especially phosphorus compounds) is an essential actuator for the performance of ecosystems in the land-sea transition zone, so that changed conditions for this, e.g. after flooding of terrestrial habitats, have a significant influence on the overall nutrient cycling of coastal ecosystems.

\section{Study sites}

The predicted sea-level rise is expected to intensify the exchange processes on flat coasts and in particular on the German Baltic Sea coast (see 3.1). Variation in flooding duration and frequency across different segments of the coast will likely result. The study area nature reserve „Heiligensee and Hütelmoor" represents a specific state of flooding intensity (rare flooding, so far about every 25 years). In order to quantify the significance of the flooding intensity, we are extending the investigations to two further locations. The study sites Polder Drammendorf in southwestern Rügen and the Karrendorfer Wiesen east of Greifswald at the Greifswalder Bodden are, in their genesis, coastal flooding peatlands and complement the study site "Heiligensee und Hütelmoor“ ideally (Fig. 2). All three study sites are briefly presented below.

The nature reserve "Heiligensee und Hütelmoor" is located on the southern Baltic Sea coast northeast of Rostock (Fig. 3). It covers an area of 540 ha with 315 ha of peatland. A depression formed by a glacial meltwater channel formed the basis for the development of the peatland (Kolp 1957). Today, peat deposits up to $3 \mathrm{~m}$ thick can be found, thinning out in the direction of the forest, with 3-10 m thick sand and glacial till layers underneath. Lake sediments can be found under Lake Heiligensee. The area was drained and used agriculturally in the 1970s, which caused a severe degradation of the upper peat layers and the introduction of nutrients. The rewetting took place in 2010 (for details see Jurasinski et al. 2018). The beach connecting the peatland with the Baltic Sea is about $3 \mathrm{~km}$ long, the study area in the Baltic Sea extends from 0 to $10 \mathrm{~m}$ water depth. The marine sediments consist of fine sand, medium sand, gravel and glacial till, whereby the finer sediments are found rather in the south and southwest, the coarser sediments as well as peat outcrops in the northeast. Due to the exposed location, wind and waves have a strong effect on resuspension and sediment rearrangement. The Warnow river plume also impacts this coastal section in typical westerly wind conditions.

The Karrendorfer Wiesen are a 350 ha large part of the nature reserve "Insel Koos, Kooser See und Wampener Riff", an important coastal bird sanctuary at the Greifswalder Bodden. They are situated on a compact peninsula, which is enclosed in the north by the Gristower Wiek and in the south by the Kooser Lake. In the terrain gently sloping to the east towards the Bodden, a small-scale mosaic of swamp and flooding peatlands has formed in a zone several hundred metres wide due to windward and leeward effects on minerogenic cores (Holz et al. 1996). Surface elevations stretch from $-20 \mathrm{~cm}$ to $+100 \mathrm{~cm}$ relative to mean water level. In the low-lying areas, fen gley soils with 13 to $28 \mathrm{~cm}$ of peat, as well as flat, eutrophic fens and mesotrophic transition mires with 38 to $60 \mathrm{~cm}$ of peat thickness have formed.

Dikes were built around the Karrendorfer Wiesen (Karrendorf meadows) in the 1850s and the area was drained. In the 1960s drainage was intensified. In 1993 large parts of the area were exposed to the natural flood dynamics again by dike deconstruction (Seiberling 2008). Thus, 
for more than 25 years now, the low-lying areas in the Karrendorfer Wiesen are frequently flooded for brief periods of time (one to several days). It can be assumed that processes are in equilibrium with the changing brackish water conditions. The work in Karrendorf is closely linked to the WETSCAPES project (Landesexzellenzinitiative MV; https://www.wetscapes.uni-rostock.de). The adjacent coastal lagoon, the Greifswalder Bodden between Rügen and Usedom, has an average water depth of 5-6 $\mathrm{m}$ and a salt content of about 6-8 $\mathrm{g} \mathrm{kg}^{-1}$. Some channels extend from the Bodden into the meadows. The sediments are muddy on the surface, often with fine and medium sand underneath.

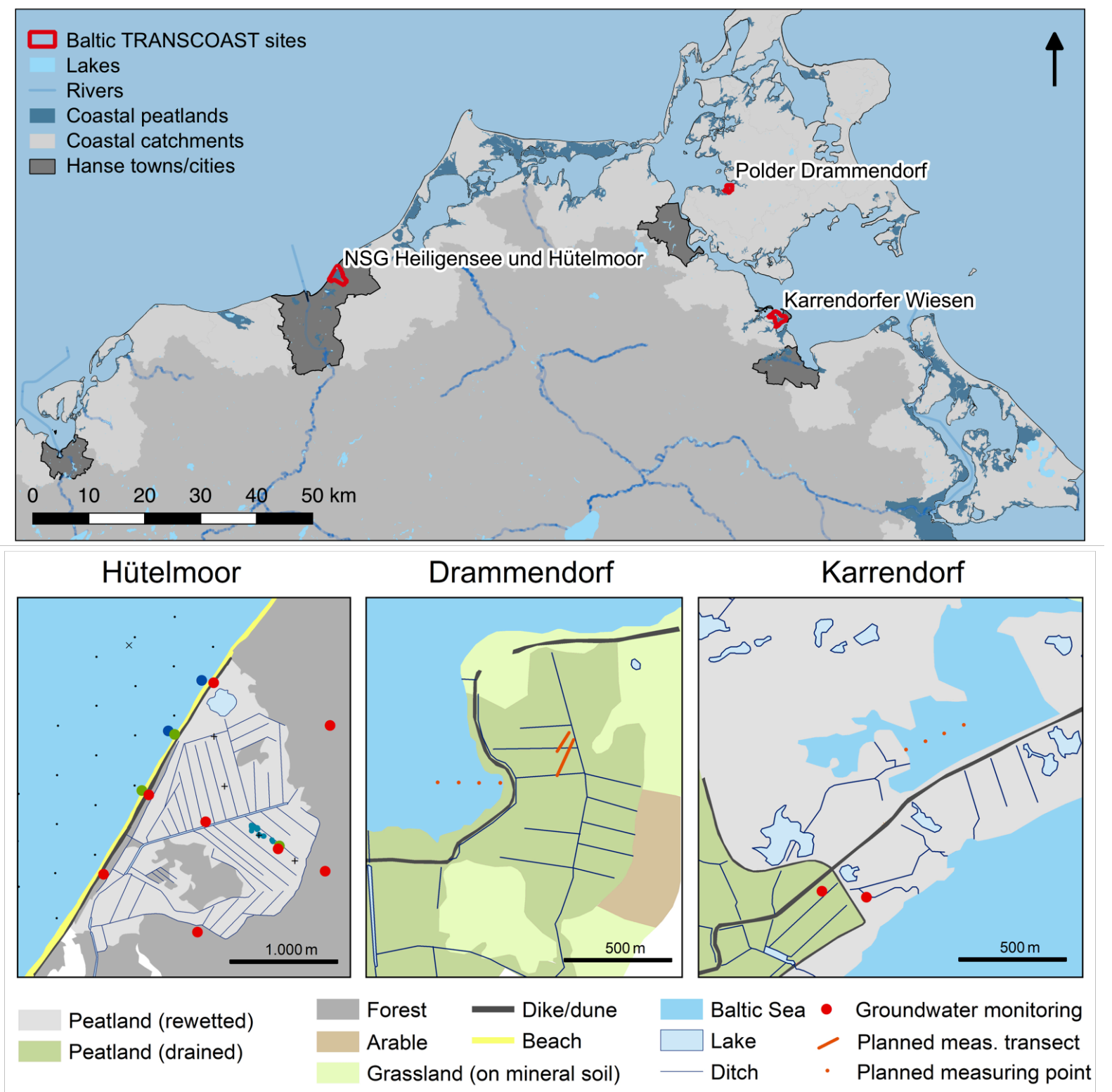

Fig. 3 Location of the three study sites on the North-East German Baltic Sea coast (top) and detailed maps of the study areas (bottom).

The polder Drammendorf is located in the southwest of the island of Rügen and has been cut off from the brackish water of the Kubitzer Bodden by a dike for more than 100 years, so that the peat was strongly degraded by drainage of varying intensity. According to a current digital terrain model, the terrain heights are between -0.6 and $3.0 \mathrm{~m}$ above the mean high tide. The 
peat thicknesses vary and are between 0.3 and $0.5 \mathrm{~m}$ in the northern part and between 0.5 and $1.0 \mathrm{~m}$ in the southwestern part. The peat is underlain by clayey lake sediments here. The peat is degraded down to a depth of 0.5 to $0.7 \mathrm{~m}$ due to drainage and partly shows a higher mineral content on the surface. Since the topography rises to heights of $34 \mathrm{~m}$ in the south, the hydraulic gradients are probably much more pronounced than in the other two study sites, which, overall, are very low. The removal of the dyke at Polder Drammendorf is planned for the winter of 2019/2020 (planning approval has already been received). From winter $2019 / 2020$ on a similar flooding regime as in the Karrendorfer Wiesen is expected. Therefore, our work will extend to the newly flooded area and less to the offshore Kubitzer Bodden. Here, a permanent boardwalk will be installed along a transect spreading across a relatively steep gradient in elevation. The Kubitzer Bodden belongs to the national park Vorpommersche Boddenlandschaft and is mostly sandy to muddy and very flat. The dike removal offers the rare opportunity to follow the change from a freshwater site to an area influenced by brackish water.

Since a double flooding event in January 2019, the nature reserve "Heiligensee and Hütelmoor", also after a long phase of freshening, has come under increased brackish water influence, so that in Baltic TRANSCOAST different conditions along the two gradients "flooding frequency" and "flooding duration" (Fig. 2) can be investigated. Due to the different terrain situations in the areas, different developmental stages of rewetting peatlands can be observed.

\section{Shared, coordinated experiments}

Based on an already existing mesocosm facility (Berthold 2018), joint experiments of several research topics will be established (Fig. 4). As an integrating central experiment, different mesocosm experiments will be carried out at the Biological Station Zingst to answer the questions how a flooding of terrestrial areas with salty/brackish water affects the microbiological conversion rates, the resulting biogeochemical fluxes, gas emissions as well as the benthic inventory of substances. These central experiments are supplemented by separate and joint laboratory experiments. The joint experiments may further develop one or several of the following research foci:

Biogeochemical focus Integrating studies on the topics in research field G, e.g. on isotopomers or isotopes in dissolved and solid phases as well as on gases in order to reconstruct their transformation pathways, could be one avenue of research. Such data using the example of nitrogen oxides can be used to demonstrate the path of formation via either nitrification or denitrification. The corresponding analyses are often challenging, especially in marine environments, because the concentrations may be in the low nanomolar range. In addition, the often difficult interpretation requires experience and knowledge of such data from microbial rate measurements. The work could thus complement ongoing doctoral projects in the G field in terms of content and contribute to a considerable additional gain in knowledge. For example, one $\mathrm{PhD}$ topic is dedicated to the occurrence and concentrations of methane and nitrogen oxides in the transition area between land and sea. The dependence of the concentrations on substrate occurrences and environmental variables is to be investigated more intensively 
through close cooperation with the other G topics. The nitrogen related processes are closely linked to the important transformations of the carbon, sulfur, and iron cycles, so that the role of biogeochemical interactions must be considered to understand the release of climate-relevant gases such as $\mathrm{CO}_{2}$ and $\mathrm{CH}_{4}$. The connection of land- and sea-side processes for trace gas formation and the role of land-side substance inputs has not been sufficiently investigated experimentally so far.

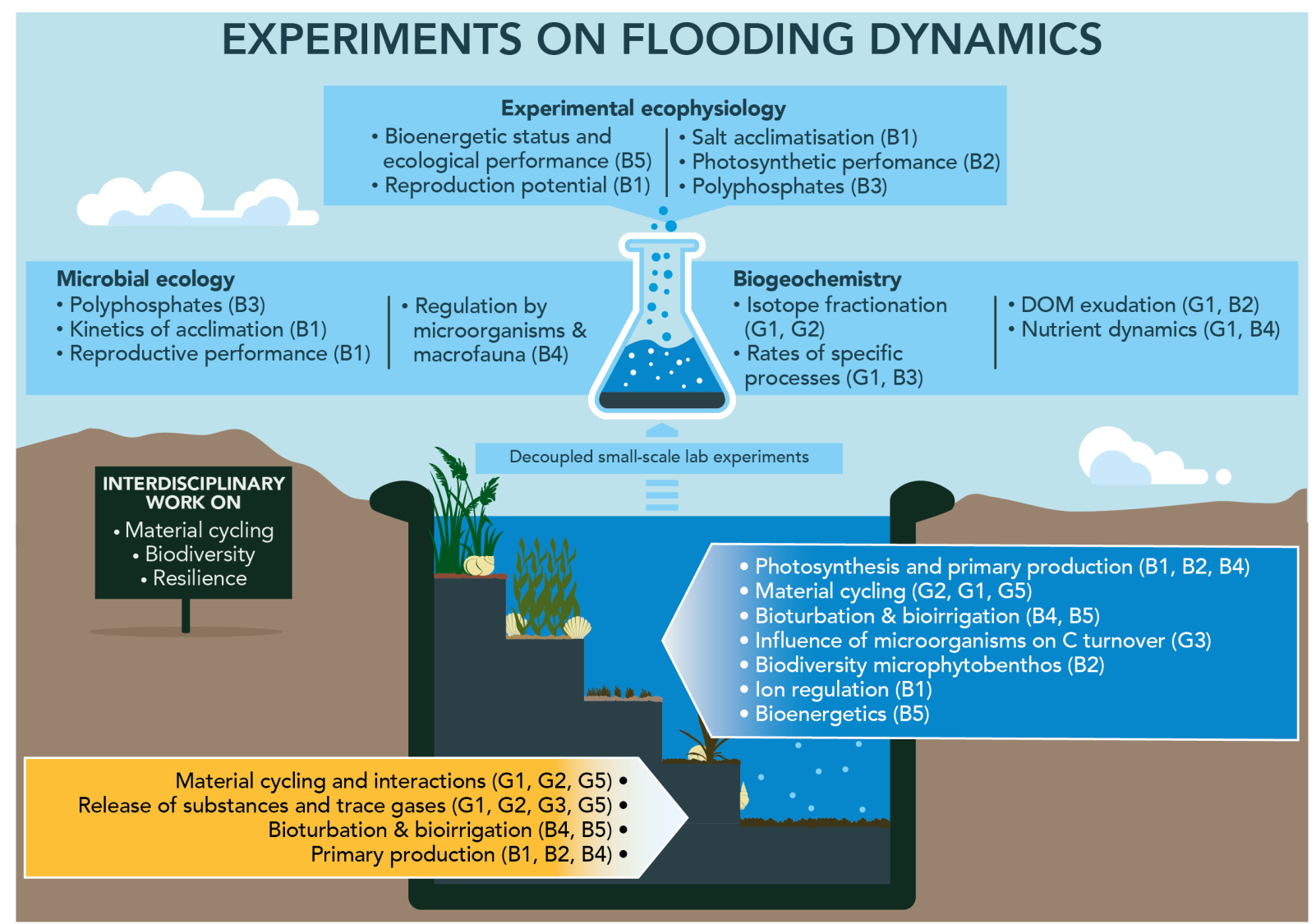

Fig. 4 Integration of experimental approaches. The integrating core is formed by joint mesocosm experiments in which sediment-borne (yellow arrow) and water-borne processes (blue arrow) are investigated. Satellite experiments on one or more topics complement the approach and should be analysed and discussed in relation to the central experiments.

Focus on microbial ecology An alternative field of research comprises microbial rate measurements, which are to be recorded by means of field or laboratory measurements. The close links between the nitrogen, carbon, sulphur and phosphorus cycles have so far been insufficiently considered. In order to understand the interactions and the regulation of rates, multifactorial experimental approaches in the laboratory based on mesocosm experiments would be optimal. In their complexity, these exceed the requirements for doctoral students, but would be planned and implemented in close cooperation with doctoral students and PIs. Our previous knowledge indicates that the availability of sulphur compounds from previous floods in the nature reserve „Heiligensee und Hütelmoor" has a regulating effect on microbial turnover. The extent to which this also affects nitrogen cycling (auto- or heterotrophic denitrification) is unknown. This would raise questions about the composition and activity of microbial communities, which could also be addressed using new microbiological methods (metagenomics, metatranscriptomics, etc.) and integrate several research topics of the research fields B and G. 
Focus on ecophysiology of aquatic pro- or eukaryotes As a third field of research, the structure of pro- or eukaryotic biocoenoses in/on the former terrestrial areas and their function in the oxygen fluxes and biogeochemical nitrogen, carbon, sulphur and phosphorus cycles could for the first time be studied in depth according to various flood scenarios. Mesocosm experiments are essential for such scientific approaches. The possible biocoenoses are macrophytobenthos, microphytobenthos or macrozoobenthos. Of particular interest are questions concerning the establishment and dynamics of new organism communities along marine terrestrial gradients after flooding events, in combination with their biogeochemical functions under these specific coastal conditions. Furthermore, ecophysiological/biochemical investigations on newly established key organisms, e.g. on the stressor salt, are also of great relevance, as there are no corresponding experimental findings in the context of flooding. For such a field of research most of the modern methods are already available. Again several research topics of the research fields $B$ and $G$ would be integrated.

\section{Research topics}

The research topics in Baltic TRANSCOAST are shortly introduced in the following. For coverage along the land-sea-gradient see figure 1.

\section{H1: Water and nutrient fluxes between coastal peatlands and the Baltic Sea}

In H1 water and solute fluxes across the coastline are assessed to reveal the underlying processes. The tasks include field monitoring at coastal peatlands and modeling of water fluxes, solute transport and biogeochemical reactions. Field work and modeling will be done in close cooperation with other PhD students.

\section{H2: Flow and solute transport anomalies in coastal fen peats}

In $\mathrm{H} 2$ the flow and transport properties of (degraded) peat soils are characterised and linked to physical non-equilibrium phenomena and geochemical transformation processes. The work program includes laboratory and field tests. The numerical depiction of the observations made at a small $(0.1-1 \mathrm{~m})$ and a larger spatial scale $(10 \mathrm{~m})$ will help us interpreting and understanding relevant processes.

\section{H3: Downscaling (process oriented localization) of larger scale simulations of sea water currents to assess interactions between sea and groundwater bodies}

In $\mathrm{H} 3$ the exchange of water, solutes and particulate matter mediated by submarine groundwater discharge (SGD) shall be quantified to assess its impact on the coastal ocean. It will be the challenge to combine physical forcing with biogeochemical transformations, dynamics of suspended particulate matter and the exchange processes between sea floor and water column. Interactions with morphological changes of the seafloor and the beach need to be considered as well.

\section{H4: Waves and turbulence on wavy coastal seabeds inducing vertical scalar transport}

The mixing processes on and above the structured permeable seabed are investigated in a defined laboratory experiment to foster our understanding of turbulence and mixing in shallow 
coastal waters. The resulting parameters regarding the fluid flow, scalar transport and mixing are provided as boundary conditions for the modeling of the large scale transport process.

G1: Impact of water and element exchange on biogeochemical processes at the Sea-Land interface of the southern Baltic Sea

The influence of water (SGD) and substances from the peatland to the Baltic Sea and vice versa, for element transformations in and fluxes from sediments and soils is in the target of this topic. By means of multi-isotope, trace element and nutrient analysis in the water column, in pore waters and in the slid phase of the sediments and the peatland on a transect between land and sea we will identify water and element sources, sinks and transformations and their regulating factors. By comparing different situations along the coast we better our understanding of the development of the biogeochemistry of coastal ecosystems under rising sea-levels.

\section{G2: Trace gas liberation from coastal peatlands overlain by brackish waters}

Central goal of this topic is the quantification of trace gas liberation $\mathrm{CH}_{4}$ and $\mathrm{CO}_{2}$ from the shallow coastal-near seafloor. Special emphasis will be given to the controlling parameters, including hydrodynamic forcing, oxygen availability at the seafloor-water interface, and seawater biogeochemical properties. The main focus will be on trace gas emissions from former peatlands overlain by brackish waters for timespans from very recent to several 1000 years.

\section{G3: Plants and microorganisms as drivers of $\mathrm{CH} 4$ production and exchange in coastal} fens

Within this topic the influence of variation in salinity and sulfate concentrations in space and time on the composition and activity of the micro-organismic community as well as on substrate supply, methane production and emission through the vegetation is assessed. We expect the microbial community composition to vary with site geochemistry, and being reflected in the methane emission patterns.

\section{G4: Influence of salinity dynamics on the release, chemical structure and biological transformations of dissolved organic matter in a coastal peatland}

We want to develop a general understanding, how the salinity dynamics in a coastal peatland affect the DOM-release, -composition and -dynamics. Based on this, joint research with the other topics shall give us a deeper insight into the effects of the salinity-affected DOM dynamics on subsequent biogeochemical and ecological processes at the land/sea-interface.

\section{G5: Connecting the $\mathbf{N}$-cycles of a coastal peatland and the Baltic Sea}

In this topic the processes converting nitrogen compounds in the water column, sediments, and peatland are disentangled to gain a better understanding of the nitrogen cycling on both sides of the coastline. Likewise important is the study of transport processes across the landsea interface in collaboration with other topics to evaluate the role of submarine ground water discharge and recycled pore waters on the sea side. The nitrogen cycle in the different environmental settings should be clearly understood and quantified to evaluate the eutrophication potential across the coastline. 


\section{B1: Composition and productivity of macropythes at the land-sea interface}

Species composition, seasonality and productivity of fen vegetation exposed erratically to brackish water intrusion will be compared with neighbouring fens fed by freshwater only. The main focus is to unravel the impact of temporal salt water intrusion on vegetation communities and matter cycles.

\section{B2: Microphytobenthic primary production in biofilms along terrestrial-marine gradi- ents}

The influence of peatland-derived organic compounds on Baltic Sea benthic diatoms will be investigated quantitatively, connecting to measurements of DOM exudation/mineralization along a coastal terrestrial-shallow water gradient to investigate the biogeochemical $\mathrm{C}$ cycle in the shallow water zone. This includes the evaluation of benthic diatom biodiversity along such gradients.

\section{B3: Microbial life and the phosphorus cycle along the terrestrial to marine gradient}

Along the redox and salinity gradients from coastal peatlands into the Baltic Sea the size and biological availability of the different phosphorus pools are changing. However, the microbial influence on phosphorus cycling along the coastal ecosystem is not well understood. The topic aims for a comprehensive understanding of the dominating microbial processes and its controls.

\section{B4: Factors controlling transport and matter cycling at the sediment-water-interface}

We will document and investigate the effects of increasing bioturbation following the colonisation of former terrestrial peat/soils after inundation. Quantification of oxygen oxygenation of sediments and tracer exchange (fluid transport) will follow. We expect effects for microbial activity and diagenetics to depend both on environmental conditions and stress to the bioturbating organisms.

\section{B5: Bioenergetics-mediated effects of multiple stressors on marine bioturbators in shal- low coastal ecosystems}

Our aim is to understand the interactive effects of multiple stressors on behavior, physiology and ecologically important of marine bioturbators (mollusks and polychaetes). The effects of stress-induced physiological and behavioral changes on ecologically important functional traits (bioirrigation and bioturbation) will be determined to develop a predictive bioenergetically-based model to assess the long-term population-level consequences of coping with multiple stressors in shallow water Baltic ecosystems. 


\section{Acknowledgments}

Baltic TRANSCOAST has been supported by our associate partners Susanne Liebner (GFZ German Research Centre for Geosciences, Germany), Gudrun Massmann (CvO University of Oldenburg, Germany), Thomas Ptak (GA University of Göttingen, Germany), Christoph Humborg (University of Stockholm, Sweden), Jan Scholten (CA University of Kiel, Germany), and Tom Jilbert (University of Helsinki, Finland), as well as by our Mercator Fellows Fereidoun Rezanazhad (University of Waterloo, Canada), Williard S. Moore (University of South Carolina, USA), Markus Hüttel (Florida State University, USA), Ulf Mallast (UFZ Centre for Environmental Research, Germany), Nils Moosdorf (Leibniz Centre for Tropical Marine Research), and Ajit Subramaniam (Columbia University, USA). The research has been and is being conducted by our PhD students Cheryl Batistel, Lennart Gosch, Sigrid Gründling-Pfaff, Cordula Gutekunst, Fouzia Haider, Miriam Ibenthal, Leonie Kandler, Petra Mutinova, Nils Karow, Natascha Ouillon, Lara Prelle, Erwin Racasa, Katharina Romoth, Hanna Schade, Robert Strehse, Viktoria Unger, Miaorun Wang, and Werna Werna (University of Rostock, Germany), and Simeon Choo, Anna-Kathrina Jenner, Matthias Kreuzburg, Xaver Lange, Simon Langer, Tina Liesirova, Marvin Lorenz, Daniel Pönisch, and Julia Westphal (Institute for Baltic Sea Research Warnemünde, Germany).

\section{References}

Andersen MS, Baron L, Gudbjerg J, Gregersen J, Chapellier D, Jakobsen R, Postma D (2007) Discharge of nitrate-containing groundwater into a coastal marine environment. Journal of Hydrology 336:98-114

Ardón M, Morse JL, Colman BP, Bernhardt ES (2013) Drought-induced saltwater incursion leads to increased wetland nitrogen export. Global Change Biology 19:2976-2985

Attrill MJ, Rundle SD (2002) Ecotone or ecocline: ecological boundaries in estuaries. Estuarine Coastal and Shelf Science 55:929-936

BACC II Author Team (2015) Second Assessment of Climate Change for the Baltic Sea Basin. Regional Climate Studies. Berlin, Springer

Baldwin AH, Hammerschlag RS, Cahoon DR (2019) Evaluating Restored Tidal Freshwater Wetlands. In: Coastal Wetlands. Elsevier 889-912

Bartlett KB, Bartlett DS, Hariss RC, Sebacher DI (1987) Methane emissions along a salt marsh salinity gradient. Biogeochemistry 4:183-202

Berthold M, Karsten U, von Weber M, Bachor A, Schumann R (2018) Phytoplankton can bypass nutrient reductions in eutrophicated coastal water bodies. AMBIO 47:146-158

Bollmann M, Bosch T, Colijn F, Ebinghaus R, Froese R, Güssow K, et al (2010) World Ocean Review: Living with the Oceans. Maribus, Hamburg

Bonn A, Allott T, Evans M, Joosten H, Stoneman R (2016) Peatland Restoration and Ecosystem Services: Science Policy and Practice. Cambridge University Press, Cambridge, UK 
Böttcher ME, Mallast U, Massmann G, Moosdorf N, Müller-Petke M, Waska H (2019) Coastal-Groundwater interfaces (submarine groundwater discharge). In: Ecohydrological Interfaces. Wiley, New York, USA

Brock J, Schulz-Vogt HN (2011) Sulfide induces phosphate release from polyphosphate in cultures of a marine Beggiatoa strain. ISME Journal 5:497-506

Burnett WC, Bokuniewicz H, Huettel M, Moore WS, Taniguchi M (2003) Groundwater and pore water inputs into the coastal zone. Biogeochemistry 66:3-33

Cahoon LB (1999) The role of benthic microalgae in neritic ecosystems. Oceanography and Marine Biology: An Annual Review 37:47-86

Church JA, White NJ, Domingues CM, Monselesan DP, Miles ER (2013) Sea level and ocean heat-content change. International Geophysics 103:697-725

Church TM (1996) A groundwater route for the water cycle. Nature 380:579-580

de Beer D, Wenzhöfer F, Ferdelman TG, Boehme SE, Hüttel M, van Beusekom JEE, Böttcher ME, Musat N, Dubilier N (2005) Transport and mineralization in North Sea sandy intertidal sediments Sylt-Rømø Basin Wadden Sea. Limnology and Oceanography 50:113-127

Dean JF, Middelburg JJ, Röckmann T, Aerts R, Blauw LG, Egger M, Jetten MSM, de Jong AEE, Meisel OH, Rasigraf O, Slomp CP, in't Zandt MH, Dolman AJ (2018) Methane feedbacks to the global climate system in a warmer world. Reviews of Geophysics 56:207-250

Dias ATC, Hoorens B, Logtestijn RSP, Vermaat JE, Aerts R (2010) Plant species composition can be used as a proxy to predict methane emissions in peatland ecosystems after land-use changes. Ecosystems 13:526-538

Donis D, Janssen F, Liu B, Wenzhöfer F, Dellwig O, Escher P, et al (2017) Biogeochemical impact of submarine ground water discharge on coastal surface sands of the southern Baltic Sea. Estuarine Coastal and Shelf Science 189:131-142

Feddersen F (2012) Observations of the Surf-Zone Turbulent Dissipation Rate. Journal of Physical Oceanography 42:386-398

Forster S, Bobertz B, Bohling B (2003) Permeability of sands in the coastal areas of the Southern Baltic Sea: Mapping a grain-size related sediment property. Aquatic Geochemistry 9:171-190

Gao H, Matyka, M, Liu B, Khalili A, Kostka JE, Collins G, et al (2012) Intensive and extensive nitrogen loss from intertidal permeable sediments of the Wadden Sea. Limnology and Oceanography 57:185-198

Gätje C, Reise K (2012) Ökosystem Wattenmeer - Austausch-, Transport- und Stoffumwandlungsprozesse / The Wadden Sea Ecosystem - Exchange Transport and Transformation Processes. Springer, Berlin

Gebhardt S, Fleige H, Horn R (2012) Anisotropic shrinkage of mineral and organic soils and its impact on soil hydraulic properties. Soil and Tillage Research 125:96-104 
Giani L, Dittrich K, Martsfeld-Hartmann A, Peters G (1996) Methanogenesis in saltmarsh soils of the North Sea coast of Germany. European Journal of Soil Science 47:175-182

Glatzel S, Forbrich I, Lemke S, Gerold G (2008) Small scale controls of greenhouse gas release under elevated $\mathrm{N}$ deposition rates in a restoring peat bog in NW Germany. Biogeosciences 5:925-935

Gocke K, Lenz J, Westphal H, Koppe R, Rheinheimer G, Hoppe H-G (2012) Diel variations in microbial activity in hypertrophic coastal waters. Hydrologie und Wasserbewirtschaftung $56: 48-58$

Gosch L, Janssen M, Lennartz B (2018) Impact of the water salinity on the hydraulic conductivity of fen peat. Hydrological Processes 32:1214-1222

Gräwe U, Burchard H (2012) Storm surges in the Western Baltic Sea: the present and a possible future. Climate Dynamics 39:165-183

Grinsted A, Jevrejeva S, Riva RE, Dahl-Jensen D (2015) Sea level rise projections for northern Europe under RCP8.5. Climate Research 64:15-23

Hahn J, Glatzel S, Köhler S, Jurasinski G (2015) Greenhouse gas exchange in a coastal fen in the first year after flooding - a systems shift. PLOSone 10:e0140657

Haider F, Sokolov EP, Sokolova IM (2018) Effects of mechanical disturbance and salinity stress on bioenergetics and burrowing behavior of the soft-shell clam Mya arenaria. Journal of Experimental Biology 221:jeb172643

Helton AM, Bernhardt ES, Fedders A(2014) Biogeochemical regime shifts in coastal landscapes: the contrasting effects of saltwater incursion and agricultural pollution on greenhouse gas emissions from a freshwater wetland. Biogeochemistry 120:133-147

Hendriks D, van Huissteden J, Dolman A (2010) Multi-technique assessment of spatial and temporal variability of methane fluxes in a peat meadow. Agricultural and Forest Meteorology 150:757-774

Heyer J, Berger U (2000) Methane emission from the coastal area in the Southern Baltic Sea. Estuarine Coastal and Shelf Science 51:13-30

Hofmeister R, Bolding K, Hetland RD, Schernewski G, Siegel H, Burchard H (2013) The dynamics of cooling water discharge in a shallow non-tidal embayment. Continental Shelf Rese$\operatorname{arch} 71: 68-77$

Holden J (2005) Peatland hydrology and carbon release: Why small-scale processes matter. Philosophical Transactions of the Royal Society A 383:2891-2913

Holz R, Herrmann C, Müller-Motzfeld G (1996) Vom Polder zum Ausdeichungsgebiet: Das Projekt Karrendorfer Wiesen und die Zukunft der Küstenüberflutungsgebiete in MecklenburgVorpommern. Natur und Naturschutz in Mecklenburg-Vorpommern 32:3-27

Horner-Devine AR, Pietrzak JD, Souza AJ, McKeon MA, Meirelles S, Henriquez M, Rijnsburger S (2017) Cross-shore transport of nearshore sediment by river plume frontal pumping. Geophysical Research Letters 44:6343-6351 
Huettel M, Røy H, Precht E, Ehrenhauss S (2003) Hydrodynamical impact on biogeochemical processes in aquatic sediments. Hydrobiologia 494:231-236

Huettel M, Ziebis W, Forster S, Luther III. GW (1998) Advective transport affecting metal and nutrient distributions and interfacial fluxes in permeable sediments. Geochimica et Cosmochimica Acta 62:613-631

Hünicke B, Zorita E (2016) Statistical analysis of the acceleration of Baltic mean sea-level rise, 1900-2012. Frontiers in Marine Science 3:125

Jankowski KL, Törnqvist TE, Fernandes AM (2017) Vulnerability of Louisiana's coastal wetlands to present-day rates of relative sea-level rise. Nature Communications 8:14792

Jeandel C (2016) Overview of the mechanisms that could explain the 'Boundary Exchange' at the land-ocean contact. Philosophical Transactions of the Royal Society A: Mathematical, Physical and Engineering Sciences 374(2081): 20150287

Johansson MM, Pellikka H, Kahma KK, Ruosteenoja K (2014) Global sea level rise scenarios adapted to the Finnish coast. Journal of Marine Systems 129:35-46

Jurasinski G, Günther AB, Huth V, Couwenberg J, Glatzel S (2016) Ecosystem services provided by paludiculture - Greenhouse gas emissions. In: Wichtmann W, Schröder C, Joosten H (eds) Paludiculture - productive use of wet peatlands. Schweizerbart, Stuttgart 79-94

Jurasinski G, Janssen M, Voss M, Böttcher ME, Brede M, Burchard H, Forster S, Gosch L, Gräwe U, Gründling-Pfaff S, Haider F, Ibenthal M, Karow N, Karsten U, Kreuzburg M, Lange X, Leinweber P, Massmann G, Ptak T, Rezanezhad F, Rehder G, Romoth K, Schade H, Schubert H, Schulz-Vogt HN, Sokolova I, Strehse R, Unger V, Westphal J, Lennartz B (2018) Understanding the Coastal Ecocline: Assessing Sea-Land Interactions at Non-Tidal Low-Lying Coasts through Interdisciplinary Research. Frontiers in Marine Science 5:342

Karow N, Bestier T, Grundmann S, Brede M (2017) PIV-LIF Untersuchung des Grundwassereintrags in marinen Bodengrenzschichten. Experimentelle Strömungsmechanik 25:551-558

Karow N, Groß J, Grundmann S, Brede M (2018) PIV-LIF Untersuchung des Grundwassereintrags in marinen Bodengrenzschichten bei verschiedenen Wellenszenarien. Experimentelle Strömungsmechanik 26:311-318

Karstens S, Jurasinski G, Glatzel S, Buczko U (2016) Dynamics of surface elevation and microtopography in different zones of a coastal Phragmites wetland. Ecological Engineering 94:152-163

Knee KL, Paytan A (2011) Submarine groundwater discharge: a source of nutrients metals and pollutants to the coastal ocean. In: Wolanski E, McLusky DS (eds) Treatise on Estuarine and Coastal Science 4:205-233

Koch S, Jurasinski G, Koebsch F, Koch M, Glatzel S (2014) Spatial variability of annual estimates of methane emissions in a Phragmites australis (Cav.) Trin. ex Steud. dominated restored coastal brackish fen. Wetlands 34:593-602 
Koebsch F, Glatzel S, Jurasinski G (2013) Vegetation controls methane emissions in a coastal brackish fen. Wetlands Ecology and Management 21:323-337

Koebsch F, Winkel M, Liebner S, Liu B, Westphal J, Schmiedinger I, Spitzy A, Gehre M, Jurasinski G, Köhler S, Unger V, Koch M, Sachs T, Böttcher ME (2019) Sulfate deprivation triggers high methane production in a disturbed and rewetted coastal peatland. Biogeosciences 16:1937-1953

Kolp O (1957) Die nordöstliche Heide Mecklenburgs. VEB Deutscher Verlag der Wissenschaften, Berlin

Kotwicki L, Grzelak K, Czub M, Dellwig O, Gentz T, Szymczycha B, Böttcher ME (2014) Submarine groundwater discharge to the Baltic coastal zone: Impacts on the meiofaunal community. Journal of Marine Systems 129:118-126

Kreuzburg M, Ibenthal M, Janssen M, Rehder G, Voss M, Naumann M, Feldens P (2018) Sub-marine Continuation of Peat Deposits From a Coastal Peatland in the Southern Baltic Sea and its Holocene Development. Frontiers in Earth Science 6:103

Lamers LPM, Tomassen HBM, Roelofs JGM (1998) Sulfate-induced eutrophication and phytotoxicity in freshwater wetlands. Environmental Science and Technology 32:199-205

Lange X (2018) Wind impacts on estuarine circulation. $\mathrm{PhD}$ thesis, University of Rostock Lange X, Burchard H (2019) The relative importance of wind straining and gravitational forcing in driving exchange flows in tidally energetic estuaries. Journal of Physical Oceanography 49:723-736

Lengerer A, Kazda M (2018) Surface interpolation of environmental factors as tool for evaluation of the occurrence of high methane and nitrous oxide fluxes. Journal of Plant Nutrition and Soil Science 181:51-60

Liebner S, Ganzert L, Kiss A, Yang S, Wagner D, Svenning MM (2015) Shifts in methanogenic community composition and methane fluxes along the degradation of discontinuous permafrost. Frontiers in Microbiology 6:356

Liu H, Janssen M, Lennartz B(2016) Changes in flow and transport patterns in fen peat following soil degradation. European Journal of Soil Science 67:763-772

Liu H, Lennartz B (2019) Hydraulic properties of peat soils along a bulk density gradient - A meta study. Hydrological Processes 33:101-114

Liu J, Su N, Wang X, Du J (2017) Submarine groundwater discharge and associated nutrient fluxes into the Southern Yellow Sea: a case study for semi-enclosed and oligotrophic seas implication for green tide bloom. Journal of Geophysical Research, Oceans 122:139-152

Maracchi G, Sirotenko O, Bindi M (2005) Impacts of present and future climate variability on agriculture and forestry in the temperate regions: Europe. Climate Change 70:117-135

Massel SR (2001) Circulation of groundwater due to wave set-up on a permeable beach. Oceanologia 43:279-290 
Meyercordt J, Meyer-Reil LA (1999) Primary production of benthic microalgae in two shallow coastal lagoons of different trophic status in the southern Baltic Sea. Marine Ecology Progress Series 178:179-191

Moore WS, Beck M, Riedel T, Van der Loeff MR, Dellwig O, Shaw TJ, Schnetger B, Brumsack H-J (2011) Radium-based pore water fluxes of silica alkalinity manganese DOC and uranium: A decade of studies in the German Wadden Sea. Geochimica et Cosmochimica Acta $75: 6535-6555$

Nerem RS, Beckley BD, Fasullo JT, Hamlington BD, Masters D, Mitchum GT (2018) Climate-change-driven accelerated sea-level rise detected in the altimeter era. PNAS 115:20222025

Neumann B, Vafeidis AT, Zimmermann J, Nicholls RJ (2015) Future coastal population growth and exposure to sea-level rise and coastal flooding - A global assessment. PLoS One 10:e0118571

Nicholls RJ, Wong PP, Burkett VR, Codignotto JO, Hay JE, McLean RF, et al (2007) Coastal systems and low-lying areasClimate change 2007: impacts adaptation and vulnerability. In: Parry ML, Canziani OF, Palutikof JP, van der Linden PJ, Hanson CE (eds.) Contribution of Working Group II to the Fourth Assessment Report of the Intergovernmental Panel on Climate Change. Cambridge University Press, Cambridge, UK 315-356

Pasquier U, He Y, Hooton S, Goulden M, Hiscock KM (2018) An integrated 1D-2D hydraulic modelling approach to assess the sensitivity of a coastal region to compound flooding hazard under climate change. Natural Hazards 1-23

Peltonen K (2002) Direct Groundwater Inflow to the Baltic Sea. Nordic Councils of Ministers, Copenhagen

Piekarek-Jankowska H (1996) Hydrochemical effects of submarine groundwater discharge to the Puck Bay (Southern Baltic Sea, Poland). Geographia Polonica 67:103-120

Reckhardt A, Beck M, Greskowiak J, Schnetger B, Böttcher ME, Gehre M, et al (2017) Cycling of redox-sensitive elements in a sandy subterranean estuary of the southern North Sea. Marine Chemistry 188:6-17

Rezanezhad F, Price JS, Quinton WL, Lennartz B, Milojevic T, Van Cappellen P (2016) Structure of peat soils and implications for water storage flow and solute transport: A re-view update for geochemists. Chemical Geology 429:75-84

Rosa E, Larocque M (2008) Investigating peat hydrological properties using field and laboratory methods: application to the Lanaie peatland complex (southern Quebec Canada). Hydrological Processes 22:1866-1875

Rossi PM, Ala-aho P, Ronkanen A-K, Kløve B (2012) Groundwater-surface water interaction between an esker aquifer and a drained fen. Journal of Hydrology 432-433:52-60

Rullkötter J (2009)The back-barrier tidal flats in the southern North Sea-a multidisciplinary approach to reveal the main driving forces shaping the system. Ocean Dynamics 59:157-165 
Sanford WE (2010) Groundwater hydrology: Coastal flow. Nature Geoscience 3:671-672

Schade H, Arneth N, Powilleit M, Forster S (2019) Sand gapers' breath: Respiration of Mya arenaria (L. 1758) and its contribution to total oxygen utilization in sediments. Marine Environmental Research 212:101-110

Schiewer U, Schubert H (2004) Carbon budget and pelagic community compositions at two coastal areas that differ in their degree of eutrophication in the Southern Baltic Sea. Es-tuarine Coastal and Shelf Science 61:89-100

Schlüter M, Sauter EJ, Andersen CE, Dahlgaard H, Dando PR (2004) Spatial distribution and budget for submarine groundwater discharge in Eckernförde Bay (Western Baltic Sea). Limnology and Oceanography 49:157-167

Schulz HN, Schulz HD (2005) Large sulfur bacteria and the formation of phosphorite. Science 307:416-418

Schulz-Vogt HN, Pollehne F, Jürgens K, Arz HW, Beier S, Bahlo R, Dellwig O, Henkel J, Her-lemann DPR, Krüger S, Leipe T, Schott T (2019) Effect of large magnetotactic bacteria with polyphosphate inclusions on the phosphate profile of the suboxic zone in the Black Sea. ISME Journal https://doi.org/10.1038/s41396-018-0315-6

Seiberling S, Stock M, Thapa PP (2008) Renaturierung von Salzgrasland bzw. Salzwiesen der Küsten. In: Zerbe S, Wiegleb G (eds) Renaturierung von Ökosystemen in Mitteleuropa. Springer, Berlin 183-208

Smyth C, Hay AE, Zedel L (2002) Coherent Doppler Profiler measurements of near-bed suspended sediment fluxes and the influence of bed forms. Journal of Geophysical Research Oceans 107.C8:19-1-19-20

Sokolova IM (2013) Energy-limited tolerance to stress as a conceptual framework to integrate the effects of multiple stressors. Integrative and Comparative Biology 53:597-608

Soomere T, Pindsoo K (2016) Spatial variability in the trends in extreme storm surges and weekly-scale high water levels in the eastern Baltic Sea. Continental Shelf Research 115:5364

Spekat A, Enke W, Kreienkamp F (2007) Neuentwicklung von regional hoch aufgelösten Wetterlagen für Deutschland und Bereitstellung regionaler Klimaszenarien mit dem Regi-onalisierungsmodell WETTREG 2005 auf der Basis von globalen Klimasimulationen mit ECHAM5/MPI - OM T63L31 2010 bis 2100 für die SRES - Szenarien B1 A1B und A2. Projektbericht, Mitteilungen des Umweltbundesamtes

Staatliches Amt für Landwirtschaft und Umwelt Mittleres Mecklenburg (StALU MM) (2015) Die Küste von Mecklenburg-Vopommern

Stüdemann O (2008) Aspekte der Geoökologie. Weissensee Verlag, Berlin 
Succow M, Joosten H (2001) Landschaftsökologische Moorkunde. E. Schweizerbart'sche Verlagsbuchhandlung, Stuttgart

Szymczycha B, Vogler S, Pempkowiak J (2012) Nutrient fluxes via submarine groundwater discharge to the Bay of Puck southern Baltic Sea. Science of the Total Environment 438:8693

Vasander H, Tuittila E-S, Lode E, Lundin L, Ilomets M, Sallantaus T, et al (2003) Status and restoration of peatlands in northern Europe. Wetlands Ecology and Management 11:51-63

Vitt DH, Wieder K, Halsey LA, Turetsky M (2003) Response of Sphagnum fuscum to Nitrogen Deposition: A Case Study of Ombrogenous Peatlands in Alberta Canada. The Bryol-ogist 106:235-246

Vousdoukas MI, Voukouvalas E, Annunziato A, Giardino A, Feyen L (2016) Projections of extreme storm surge levels along Europe. Climate Dynamics 47:3171-3190

Weedon JT, Kowalchuk GA, Aerts R, van Hal J, Logtestijn R von, Taş N, Röling WFM, Bodegom PM von (2012) Summer warming accelerates sub-arctic peatland nitrogen cy-cling without changing enzyme pools or microbial community structure. Global Change Biology $18: 138-150$

Weisse R, Bellafiore D, Menéndez M, Méndez F, Nicholls RJ, Umgiesser G, et al (2014) Changing extreme sea levels along European coasts. Coastal Engineering 87:4-14

Wen X, Unger V, Jurasinski G, Koebsch F, Horn F, Rehder G, Sachs T, Zak D, Lischeid G, Knorr K-H, Böttcher M, Winkel M, Bodelier PLE, Liebner S (2018) Predominance of methanogens over methanotrophs in rewetted fens characterized by high methane emis-sions. Biogeosciences 15:6519-6536

White E, Kaplan D (2017) Restore or retreat? Saltwater intrusion and water management in coastal wetlands. Ecosystem Health and Sustainability 3(1):e01258

Winter AG, Deits RLH, Hosoi AE (2012) Localized fluidization burrowing mechanics of Ensis directus. The Journal of Experimental Biology 215:2072-2080

Witte S, Giani L (2016) Greenhouse gas emission and balance of marshes at the southern north sea coast. Wetlands 36:121-132 